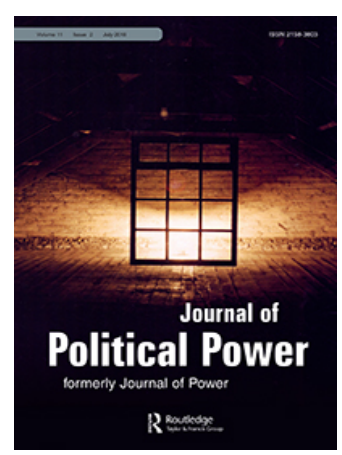

Journal of Political Power

\title{
Freedom can also be productive: the historical inversions of 'the conduct of conduct'
}

\section{Carlos Palacios}

To cite this article: Carlos Palacios (2018) Freedom can also be productive: the historical inversions of 'the conduct of conduct', Journal of Political Power, 11:2, 252-272, DOI: 10.1080/2158379X.2018.1478641

To link to this article: https://doi.org/10.1080/2158379X.2018.1478641

\section{曲 Published online: 30 May 2018.}

Submit your article to this journal $\sqsubset$

Џ Article views: 164

Q View related articles $\asymp$

View Crossmark data $\complement \pi$ 


\title{
Freedom can also be productive: the historical inversions of 'the conduct of conduct'
}

\author{
Carlos Palacios \\ Department of Sociology, Macquarie University, Sydney, Australia
}

\begin{abstract}
The Foucauldian conception of power as 'productive' has left us so far with a residual conception of freedom. The article examines a number of historical cases in which 'relationships of freedom' have potentially come into existence within Western culture, from 'revolution' and 'political truth-telling' to 'cynicism' and 'civility'. But the argument is not just about demonstrating that there have in fact been many historical inversions of 'the conduct of conduct'. It is about theorizing how freedom can be 'productive' or give rise to cultural norms if any such inversion can only come into being as an event in itself.
\end{abstract}

\section{KEYWORDS}

Foucault; Judith Butler; Arendt; parrhesia; performativity

\section{Introduction}

Freedom does not seem to exist for Foucault except as a condition for power. This, of course, is not objectionable in itself. Nothing, in fact, is objectionable in principle when social life is interpreted as a combative struggle through the lens of a pervasive power. That nothing is fundamentally objectionable does not mean, however, that one cannot object. For Foucault, the upside of an analysis of experience in terms of power is precisely the opposite: one can always object. The modern individual may remain a 'subject', but a subject that is always free to resist an injunction by considering 'other reasonable options' (Foucault 1997, p. 296).

While there is an essential freedom to intervene in the direction of one's own life and that of others in this scheme, a freedom that Judith Butler (2002) suggests is always 'critical', in the sense of interrogatory, this is still a freedom that can never really be expected to have a productivity on its own. If, 'following Foucault, we [have come to] understand power as forming the subject as well, as providing the very conditions of its existence and the trajectory of its desire' (Butler 1997b, p. 2, original emphasis), it must be equally recognized how, thanks to him, we have also come to understand freedom as not forming or producing the subject. The discursive norms that allow us to recognize ourselves as beings of some sort or another exclusively belong to the history of power (Butler 1997a, p. 28-38). While freedom may add an element of 'inventiveness' (Butler 2005 , p. 18) to our self-formation and arts of existence, it is nonetheless bound to remain in the margins of our historical self-intelligibility.

CONTACT Carlos Palacios carlosmpalacioso@gmail.com @ Department of Sociology, Macquarie University, W6A building, North Ryde, 2109 Australia.

(c) 2018 Informa UK Limited, trading as Taylor \& Francis Group 
Foucault tends to reduce the role of freedom in human relationships to a residual, albeit indispensable, factor. It is a factor that provides political hope to the extent that an ontological condition of freedom allows us to imagine that human 'relationships are in perpetual slippage from one another' and are hence analyzable with a critical lens in terms of 'strategics' and 'reversibility' (Foucault 2007a, p. 65-66). But the freedom of a subject that can object but never truly create cannot be other than disruptive (see e.g. Isin 2012, p. 119-126). Its actual products, what it produces, must take again the form of power. Another iteration of 'the conduct of conduct' must follow, even if from a certain comparative angle it is possible to think of these products as 'counter-conducts' (see Davidson 2011, p. 27).

Isin (2012) has explored how the critical potential of such residual moments of freedom may be crystallized into more stable claims in a political culture by taking the form of a certain right. Thus, he has been able to reach beyond the frame of 'counterconduct' by considering how 'acts of citizenship' can leave a recognizable trace and through their disruptions materialize a progressive and continuing demand for the right to have rights. I intend to go even further in this paper and contend that freedom has a productivity of its own, one that does not require a framework of sovereign or governmental power to be readable as socially effective. This productivity was broadly articulated by Butler long ago, even if she has never left an understanding of freedom as residual:

I would suggest that a fundamental mistake is made when we think that we must sort out philosophically or epistemologically our 'grounds' before we can take stock of the world politically or engage in its affairs actively with the aim of transformation. The claim that every political action has its theoretical presuppositions is not the same as the claim that such presuppositions must be sorted out prior to action. It may be that those presuppositions are articulated only in and through that action and become available only through a reflective posture made possible through that articulation in action. (Butler 1995, p. 128-129)

Through a 'reflective posture', freedom has the capacity to give rise to social norms, norms that may be of a very particular type, but that still manage to shape our ways of relating to each other and affect the process of self-formation. Freedom can do more than disrupt power, reverse power and then translate into power in order to become productive. It can become its own reflection, a full-fledged inversion of 'the conduct of conduct'. Most of the time, these inversions escape articulation, history forgets them and their 'grounds' never solidify. But, on occasion, they enter and become part of life and enliven discourse, becoming thinkable forms of practice that, although not always successful, can still endure their own contingency and even give rise to their own cultural convention.

This article examines a number of historical cases in which it can be potentially said that 'relationships of freedom' have come into existence within Western culture, from 'revolution' and 'political truth-telling' to 'cynicism' and 'civility'. The argument, however, will not just be about demonstrating that there have in fact been many 'historical inversions' of the conduct of conduct, but, more broadly, about making the point that all such inversions must be qualified as 'historical' to the extent that they constitute, in every instantiation, an event in itself. The first part of the paper explores a way of conceiving a sociology of freedom within the very conceptual terms of historical 
problematology' established, or at least refined, by Foucault (see e.g. Osborne 2003, Rabinow 2003). Then, based on this conceptualization of freedom, the second part embarks on a reflection upon the increasingly unthinkable phenomenon that is freedom as a type of productive force effectively shaping relationships with oneself and others. The discussion will remain within the limits of post-structural theory throughout the paper. The conclusion elaborates, however, on why, unlike liberal-democratic theory, this theoretical tradition may still be able to find critical advantages in a marked opposition between power and freedom.

\section{Beyond a sociology of power}

Can freedom, as Hannah Arendt (1998, p. 190-191) in her own style of theorization long ago contended, at rare times have a productivity of its own and form actual relationships? Further, might freedom even have its own productive dimension within most relationships, just as many of us have come to assume with Foucault that power does? Arendt's account of the experience of power as a matter of mutuality and political vibrancy is empirically suggestive and particularly useful to open up a conception of productive freedom. I will in fact regard her work in the second part of the paper as the ideal entry point into a reflection on freedom's own type of social effectivity or 'productivity'. But in none of her accounts can one find a historicist definition of freedom as a situated form of problematization. She did of course meticulously explore the historical emergence of what she saw as a rather spontaneous, if contingent, faculty (see e.g. Arendt 1978, 2005). But I would like to examine the historicity of freedom as a problem or as just another problematic of thought within the multiple games of truth of Western culture, and, to this end, Foucault's own work can be uniquely elucidating. ${ }^{1}$

Foucault may not have been as closed off to the consideration of freedom on its own as we have come to believe. As he revealingly confessed during a roundtable discussion after his lecture What is Critique?, he did not 'absolutely' reject but had simply been avoiding for a long time 'the problem of will' and 'originary freedom' (Foucault 2007a, p. 75-76). In particular, there is a strong emphasis during his two last courses at the College de France on the idea of political truth-telling or parrhesia as 'actually the exercise, the highest exercise, of freedom' (Foucault 2011, p. 67). In fact, in a way, Foucault assumes freedom to be much more of an 'ontological condition' than Arendt, as he himself once put it (Foucault 1997, p. 284). One could say that he just never encountered a way of synthetically grasping this widely relevant condition through a historicist method just as he was able to do with power through 'the conduct of conduct'. Before delving into this mode of interpretation, however, I would like to consider briefly the established interpretation of Foucault's sociology of human relationships - particularly with the help of Butler, even if Butler will be equally helpful to go beyond the frame of power.

\subsection{Residual power}

'From the moment one man began to stand in need of the help of another ... slavery and misery were soon seen to germinate' (Rousseau 1923, p. 214-215). As analysts of power have done since the time of Hobbes and Rousseau, Foucault recognizes in 
human relationships something essentially tragic. What differs in his conception is the way he turns this tragedy on its head. If every social relationship can be said to be one where 'one person tries to control the conduct of the other', it 'is because there is freedom everywhere' (Foucault 1997, p. 291-292). 'Power', whether it is a perceived boundary for conduct or an immediate threat of force, is characterized in this scheme for expecting a certain reaction from the individual. Yet, in their condition of freedom, individuals can choose to be skeptical, do something unexpected and alter a pressure situation in some way. As Foucault explains, if there were no possibility of resistance (of violent resistance, flight, deception, strategies capable of reversing the situation), there would be no power relations at all' (Foucault 1997, p. 292).

Foucault does not follow the pessimism of Hobbes, who once tragically imagined that we all are by nature skeptical subjects, beings that lack an inner sense of morality, a distinct capacity for dispassionate deliberation, and a fundamental concern for anything other than self-preservation (Hobbes 1998, p. 85, 39-40, 88). His insight is rather that being skeptical is always a potential alternative for the very reason that we can all strive to be ethical, reflect on our own about what is right, and choose between at least a few options of conduct and forms of existence. His reply to Rousseau's lamentation, in this same positive vein, would be that, even in the worst of cases like slavery, 'a power can be exercised over the other only insofar as the other still has the option of killing himself, of leaping out the window, or of killing the other person' (Foucault 1997, p. 292).

In principle, a 'skeptical' attitude could be seen as a void, as a position that, already lacking any content itself, goes on to empty of meaning and value whatever discourse, theory or opinion it confronts by destabilizing even its most commonsensical premises and scavenging for disproving counterfactuals (see e.g. Butler 1997b, p. 45). Foucault went beyond this extreme interpretation, endowing the capacity for skepticism with a certain general value, yet he still rejected the possibility that a skeptical subjectivity could come up with any content of its own. ${ }^{2}$ He could at most refer us to a limitattitude' or 'the undefined work of freedom' (Foucault 2007a, p. 113-114). Even if it is the case that the large majority of individuals have a certain freedom to be skeptical as part of their ontological condition, the expression of that skepticism, for Foucault, cannot in itself be productive. Our inner skeptic only amounts to a 'virtual "instant" or 'gesture' of reflection (Rossi 2017, p. 346-347) - while sociologically absent, it accounts for the freedom that is left from a social world in contention.

In certain lectures, Foucault gave more genealogical shape to this thesis by tracing the development of our skeptical capacity through the historical case of the 'critical' attitude. It is in this vein that he explored, for example, the 'perpetual question' of 'how not to be governed like that' (Foucault 2007a, p. 44, original emphasis) and its correlative notion of 'counter-conduct', explaining how this term was able to avoid a potential 'substantification' of the critical subject, as would be the case with notions like 'dissident' (Foucault 2007b, p. 202). He wanted to avoid suggesting, in other words, that there was anything unique to the experience of 'counter-conduct' that was not already found in the conceptualization of 'conduct', beyond a certain critical correlation in regards to pre-existing power, one 'that may well be found in fact in delinquents, mad people, and patients' (ibid., p. 202). 
Paying particular attention to Foucault's last lectures on ethics, Butler has further elaborated on the singular 'critical move' embedded in Foucault's sociology of power as one where the relation between a subject and a moral system is 'neither predictable nor mechanical' (Butler 2002, p. 217):

The injunction compels the act of self-making or self-crafting, which means that it does not act unilaterally or deterministically upon the subject. It sets the stage for the subject's self-crafting, which always takes place in relation to an imposed set of norms. (Butler 2005, p. 18-19)

The moment one has to create a narrative to give an account of oneself or deploy speech (or conduct) in some way to address others, one and others become subjects that are open to revision. The reiteration of any social form of intelligibility always poses a risk, for the cost is that one may well be transforming the terms through which we have come to effect mutual understanding and recognition, however fair or injurious these terms are (Butler 1997a, 2005). But, if there is always a chance for a felicitous performative effect in this risk, it is only to bring about a 're-signification' of those norms (e.g. Butler 1997a, p. 41), norms that will in any case continue to interpellate us as 'subjects', even if, in the case that the resignification is successful, as subjects with a horizon of activity and agency that has been 'renewed' (Butler 2010, p. 150). While Butler has come to stress the more unexpected and 'perlocutionary' aspects of this subject renewal (ibid., p. 147-154), and even the less 'inadvertent' forms of political agency it can include, such as performative alliances achieved through assembly (Butler 2015, p. 32), it is still the case that iterability thus becomes the non-place of subversion, the possibility of a re-embodying of the subjectivating norm that can redirect its normativity' (Butler 1997b, p. 99). She can only frustratedly refer us to 'something like the unconscious of power', since freedom remains for her, at its most independent, a matter of 'productive iterability' (ibid., p. 104).

Freedom appears in a strict Foucauldian reading as that space which gives individuals the opportunity to modify and react to their existing relationships, to themselves act upon conducts, but never as a specific form of relating to others in itself. In most human relationships, there would be room for skepticism: whatever I am invited to do or think or say is only an option and not necessarily the best one for one's case. But from that skepticism can only come out another, modified relationship of power - not necessarily one that involves an Other, but simply it could appear inasmuch as one then seeks another form of conducting oneself. In this view, a critical sociology of freedom could only ultimately refer us to either a world with a 'minimum of domination' (Foucault 1997, p. 298-299), in which everyone's active, tireless skepticism constantly keeps power at bay, preventing the establishment of dominant relationships; or a world with a 'cynical' ethics or philosophy, in which everyone's skepticism turns inward forming a mode of existence based on the rejection of this life and all of its expressions of power, and on an orientation to an 'other world' which can only be negatively defined as one where 'every individual forms a vigilant relationship to self (Foucault 2012 , p. 315). In other words, from this perspective, the freedom of a skeptic can only become productive through power. This is a skeptic that can only become critical of things, and out of that criticism relationships of power either become more agonistic, or one's conduct of the self becomes more 'cynical', in the ancient sense recovered by Foucault of having to put everything into question as part of one's moral mission (see e.g. Foucault 2012, p. 284-285). ${ }^{3}$ 


\subsection{Relationships of freedom}

Foucault explored the philosophical tradition of Cynicism as part of a much wider investigation into the ancient practice of parrhesia. This practice was examined from many different angles and at a variety of junctures in Antiquity during his last three courses at the Collège de France (Foucault 2004, 2011, 2012), describing, not always chronologically, the transition of parrhesia from a political form of truth-telling that could bring about an ethical differentiation among the vocal citizens of the polis, to a much more personal ascetic exercise that could just be practiced among friends or strangers if with beneficial side effects for the body politic. It is the beginning of this transition which can be illuminating for a problematological sociology of freedom, before a political and largely spontaneous parrhesia becomes a whole ethical philosophy of life and aesthetic programme of conduct or 'art of existence' (see e.g. Foucault 2012, p. 160-163).

It may be true that Foucault's interest in this cultural practice that consisted of speaking one's mind during the Greek assembly came from the opposite direction. He postulated it as the first formulation of governmentality (Foucault 2011, p. 159). And yet, while parrhesia clearly appears as linked to the whole political structure of ancient democracy in his analysis, the practice itself of this fearless truth-telling does not seem to consist of governing oneself or others - the latter is rather a development that follows the crisis of a political model organized around parrhesia. Before this democratic crisis and ethico-political transformation that Foucault locates at the start of the fourth century B.C. occurs, parrhesia simply appears as the prerequisite for a functional government. ${ }^{4}$ While later it becomes the very foundation of conduct in Greek culture, for the prince as much as for the ordinary citizen (see e.g. Foucault 2012, p. 86), in its classical form parrhesia unquestionably stands for an expression of freedom.

In a sense, parrhesia was the right to freedom that the (male) citizens of Athens and other city-states possessed by virtue of being born there, the democratic right to speak freely to all the other citizens of the polis and engage in an agonistic politics of rational debate (Foucault 2011, p. 105, 2012, p. 34-35). But that this was a right only meant that a certain number of individuals could venture putting it into practice. This is perhaps why someone like Arendt compares the law of the polis to a 'wall' or 'enclosure' (1998, p. 63-64; see also Arendt 2005, p. 121-130). For the freedom that parrhesia entails is definitely not one that can be granted or obtained by means of a right. As Foucault remarks to his audience, it does not refer to 'the freedom of speech' (Foucault 2011, p. 188). It involves a mode of acting and relating to others and oneself; in precise terms, a 'dangerous exercise of freedom' (ibid., p. 67). The one who spoke frankly in the assembly and told the 'truth' was always taking a considerable risk. A truth-teller is, as Socrates would later on articulate, the one who says what he thinks, in his own ordinary language, and using 'no more than the series of words and phrases which occur to him' (ibid., p. 313). Being this open about one's true thoughts and leaving the art of rhetoric behind represented an act of courage, to the extent that it exposed an unfiltered individual to the reactions of high-ranking citizens, who were in a way his political rivals, and who could be justified in being critical of him and even taking extreme measures such as ostracizing him, exiling him or condemning him to death. 
It is in the contrast Foucault draws between rhetoric and parrhesia that the distinction between power and freedom becomes most defined: 'rhetorical language is a language chosen, fashioned, and constructed in such a way as to produce its effect on the other person' (ibid., p. 314). The very purpose of rhetoric is to create a 'bond of power', Foucault affirms, through the use of a certain skill and well-defined technique which consists of styling discourse in such a way that it becomes believable and persuasive (Foucault 2012, p. 14). To be a successful rhetorician one does not need to convey a truth one trusts thus revealing one's inner thoughts, but only to produce a sense of conviction in the listener. It is the art by which one forges 'a constraining bond between what is said and the person or persons to whom it is said' (ibid., p. 13). The parrhesiastes, on the other hand, practically seeks to break that bond, in the sense that, without risking exposure, he could not be a truth-teller - he could not attach his 'signature' to what he says, and affirm that his speech belongs to his own opinion rather than being borrowed through the mastery of discourse from an agreeable understanding of things. His speech is inherently polemic and localized. If it requires courage it is because it calls him to express what he thinks is true and appropriate in relation to a very specific situation, even if doing so involves putting in danger the very continuity of his immediate relationships (ibid., pp. 10-14).

Whether the parrhesiastic act of a citizen was found to be distasteful and offensive or it was rather welcomed, a relationship of freedom would have been initiated. It was the democratic principle born in Athens that all citizens should be able to establish such relationships and gain through them the virtue and right to govern others (Foucault 2011, p. 155-158). That those relationships were made possible thanks to a cultural convention does not mean that they pointed to a calculated form of conduct; that ultimately they belonged to the dimension of power. I delve into this issue in the second part of the paper. At this point, I would instead like to draw what I think is a reasonable generalization about what differentiates a relationship of freedom from one of power.

\subsection{Freedom as its own problem}

Mirroring Foucault's memorable construct, it becomes possible to suggest that there are relationships or at least moments in a relationship that are not about the conduct of conduct but rather about the 'reflection of reflection'; about managing to reflect in practice one's own reflections. ${ }^{5}$ For an individual to relate through freedom, 'reflection' is doubly significant. It is first of all what prompts agency in this case, for a relationship of freedom stems from a desire to manifest one's inner thoughts to what broadly speaking can be considered to be the currently powerful. It is that desire which carries the action rather than a calculation of conduct, which means that it is a type of agency that is at the same time characterized by the hope that out of such a risky performance something meaningful can emerge - through the expectation that whatever is 'reflected' in action can manage to incite a productive rather than repressive reaction. The orientation of the subject's desire can in this case be 'apprehended' but not always 'recognized' (Butler 2016, p. 3-11).

Freedom would refer to all those human initiatives and forms of expression that strive to 'reflect' an individual's own personal take or 'reflection' on a certain matter, 
regardless of their position vis-à-vis the materiality of power (as embodied in present discourse, knowledge, institutions, status, etc.). What is reflected in practice will never be an exact mirror image of what one would have wanted to do or say - this is what Butler would call the performative element of our conduct. But this does not necessarily mean that freedom is a kind of surplus of power, the unexpected side of every performance (c.f. Butler 1997b). The implication of the performative is rather that, the less calculated an action is, that is, the more open it is to articulate rather than reiterate, the higher the chance that this action will cost us (see Butler 2005, p. 120-135). Speaking or acting in a way that reflects one's own peculiar reflections is never easy or straightforward. It threatens the performer with the risk of losing herself in an action that is not fully intelligible to her or anyone else, and, in cases like parrhesia, of undermining her standing in society in some considerable way.

Instead of referring us to a highly definable 'conduct', this definition uses the two meanings of the term 'reflection', whose contours in each case are intentionally hazy. In the first term, the allusion is to a certain transparency in behavior that differs from the kind of agendas and desires of control that populate conduct. ${ }^{6}$ Yet, what is captured is only a 'reflection', a glimpse of meaningfulness, what Arendt would call an 'appearance' (see e.g. Arendt 1978, p. 21; 1998, p. 179). We need to speak in terms of appearances or 'reflections' when we recognize that only 'up to a point we can choose how to appear to others' and, at times, we are 'willing to risk the disclosure' (Arendt 1978, p. 34; 1998, p. 180, original emphasis). Those moments of freedom, when a well-known and pre-structured narrative does not guide the instrumentalization of our conduct, may not allow for an objective or clear-cut interpretation of what we are trying to express, but they do suggest to our spectators that there is at stake a distinct way of approaching a situation. That distinct way is in turn marked by the second term, 'reflection' in the sense of mental reasoning. The reference is again here non-specific. It does not point to 'reflexivity' as some kind of special human capacity in the way many late-twentieth century sociologists did (see Rose 1996). The difference with 'conduct' would not be that in these cases there is more thinking involved. Following Foucault, one can say that there is 'thought' in every human practice, regardless of how purposeful or automated it is (Foucault 1988, p. 155). 'Reflection' simply refers us to what a specific individual thinks, to a precise locus, rather than to an immediately recognizable and therefore generic calculation for conduct.

The fact that this definition accepts that every individual can have a particular way of seeing the world due to her partial position in it does associate it with the epistemological view of Arendt, who, similarly drawing on a Socratic contrast with rhetoric, invites us to acknowledge the unique standpoint of every human being, the perspectival 'dokei moi' or 'it-seems-to-me' (Arendt 1978, p. 21, 2005, p. 12-15). Yet, this association does not make this definition reliant on an existential phenomenology or fundamental faculty. It rather assumes that human experience has been historically organized around different kinds of problems, and that, at least in our culture, one of those problems has been that of how to act in a way that reflects one's own reflections - just as another one has been that of how to adequately direct conduct. ${ }^{7}$ This problematization of freedom has existed at least since the origins of democracy with parrhesia, when being vocal about what one truly thought became a cardinal political task. Nevertheless, it must be noted that the way I have chosen to define it does capture 'freedom' as the exact opposite of 'power' - which makes this definition more and, perhaps at the same time, less arbitrary. 
A relationship of freedom requires the presence of power precisely in the same way a relationship of power requires the presence of freedom. If the exercise of power consists in directing the conduct of free individuals who could just as well act otherwise, the exercise of freedom consists in challenging the perception of powerful subjects who could just as well take their own understanding for granted. For freedom to become a problem there must be a minimum of - material, not relational - power, a risk in articulating one's tentative thoughts. Every time something is left unsaid in a conversation due to the fear of the reactions and repercussions that saying so could cause (e.g. looking out of place, being yelled at, losing status, receiving a disciplinary response, etc.) is a time when the opportunity for a relationship of freedom has been lost. Without the feeling that there is a certain level of risk in the way one would be perceived if one were to express oneself openly and without calculation, freedom is no longer a problem - or at least the reflection of reflection in one's case becomes a given.

I explain freedom in this way in order to show how closely its definition mirrors Foucault's conception of power, where for example he states that:

power relations are possible only insofar as the subjects are free. If one of them were completely at the other's disposal and became his thing, an object on which he could wreak boundless and limitless violence, there wouldn't be any relations of power. (Foucault 1997, p. 292)

But in spite of the parallel that I have drawn with Foucault's mode of description - the way both power and freedom could be said to ontologically require each other's presence - the truth is that, even in the extreme states of absolute resistance and absolute domination a certain problem, in each case, remains. One could say that the history of power as the conduct of conduct actually begins with the problem of the sovereign who, having complete authority and control over his subjects, still does not know what to order. For a king it may be unproblematic to wield power, in the sense that its application is likely to reach its aim and subjugate the target to his will. Yet, the problem that started with thinkers like Machiavelli is that of what the orientation of this will should be, the principle of its rationality (Foucault 2007b, p. 242-248; Hirschman 1997, p. 33-35; c.f. Dean 2013, p. 71-74). Directing conduct really creates, then, two problems of calculation, one regarding its tactics (a 'how' problem) and another one regarding its programmes (a 'what' problem).

In the case of freedom, the problem in general is not one of calculation but one of courage - although not because exposing one's reflections solely depends on the willpower of the individual. There will always be contexts that encourage more, or less, this problematization of experience (as Arendt for example argued, in an authoritarian regime the citizen completely loses her capacity to intervene and express herself through freedom: there is an 'impotence or complete powerlessness' that cannot be reproached (Arendt 2003, p. 43)). Nevertheless, it is still the case that all relationships of freedom stem from a certain individual skepticism and that they cannot come into existence without a measure of courage. One may have infinitely imaginative and incisively critical 'reflection', but unless the risk to express and embody that reflection is taken, that critical purview cannot give rise to a relation of freedom. Someone within a social movement relates to others in terms of freedom, for example, not the moment she finds herself in her own mind to be fully convinced of a different way of judging things, next to others who have also come to that understanding. A relation of freedom 
would rather appear in those moments she displays a certain courage to risk uncertainty, when she is confronted with others who have a settled view of things and, in deciding to communicate or manifest her more or less elaborate skepticism, she knows she is exposing herself to the possibility of seeming unrecognizable, unintelligible, unbearable, even to herself.

A certain courage is still needed, then, even when the materiality of power is absent, with its normative force and disciplinary threat. To take an extreme example on which I will soon elaborate, even when revolutionaries are successful in their interventions and are no longer exposed to the risk caused by the immediate presence of power, they still engage in relationships of freedom due to the courage that it takes to act with uncertainty, without a reliable common ground. In such a scenario, one must have the courage to explore questions of truth by oneself and deal with the incipiency of meaningful practice.

\section{The productivity of freedom}

Just as a state of domination became something thinkable for Foucault at some point, that state in which freedom is nullified or, better, practiced 'only unilaterally' (Foucault 1997, p. 283), we have considered as a real possibility the opposite scenario: that of a relationship in which calculation is absent or at least momentarily left aside by one of the parties. The fact that all individuals necessarily affect and influence each other through what they do and that they could always come up with an answer as to what could be expected to follow from their actions is not sufficient reason to assume that their mutual reactions are universally reducible to some passive or active form of 'the conduct of conduct'. The agonism of their relationships can just as well be the effect, on occasion, of creative acts of freedom. Departing from an unexpected 'action' rather than a calculative 'conduct', Arendt, for example, makes this very point: 'Since action acts upon beings who are capable of their own actions, reaction, apart from being a response, is always a new action that strikes out on its own and affects others' (1998, p. 190).

It becomes relevant, in this rather Arendtian light, to include within the productivity of value and meaning that results from any social relationship a potential for effects that belongs, properly speaking, to freedom rather than power. One may not have to stray too far from the current understanding of the Foucauldian subject in order to incorporate this possibility (c.f. Luxon 2008). If, as Arnold Davidson has reminded us, Foucault sociologically departs from a 'multiplicity of force relations immanent in the sphere in which they operate and which constitute their own organization' (Foucault 1998, p. 92), then freedom can simply be taken to be at times one of those immanent forces. Davidson's commentary can be illuminating in this sense:

A force is not a metaphysical substance or abstraction, but is always given in a particular relation; a force can be identified as any factor in a relation that affects the elements of the relation; anything that influences the actions of individuals in relation, that has an effect on their actions, is in this sense a force (Davidson 2011, pp. 28, original emphasis)

Nevertheless, while a definition of freedom based on the courageous confrontation of power and the autonomous exploration of truth may lead to this conclusion, it says 
little about how this inverse force can be studied and evidenced in concrete cases. 'The subject', as a normative fold that is invariably 'subjected', remains untouched. With the help of Arendt, Richard Sennett and, again, Foucault, I will now explore the matter of how relationships of freedom can come to have an effect that is socially consequential and graspable.

\subsection{Social effectivity}

Knowing when a certain practice of intervention has been effective is problematic in general, full of contingencies and mismatched realities. But it is particularly so when conceptualized as 'the reflection of reflection', for its peculiar impact may well be overlooked and interpreted, instead, as a calculated outcome. As an empirical social phenomenon, 'effectivity' - the productivity of practice - becomes immediately discernible only on the condition of some pre-written or somehow pre-stated theory or contract. And yet, as Butler manages to grasp in the quote cited in the introduction, there can be a type of intervention that does not depart from any agreement or manifested 'theoretical presuppositions'. In such cases, when one is faced with the absence of a readily applicable script or principle, the only methodological resource left is, in Butler's words, a 'reflective posture'. The fact that one must come up with a judgment about the question of effectivity itself ex post facto does not mean that the answer will be arbitrary or forever confined to the realm of theory. It just means that the usefulness of an assessment will only go as far as its ability to creatively gather the 'grounds' or strategic logic that a whole culture already more or less intuitively associates with that practice.

Arendt carried out this kind of articulatory exercise in her classic book On Revolution (Arendt 2006). In this text, she concentrates on the strange fact, long perceived by historians, that the eighteenth-century revolutions were brought about by rather conservative 'men who were firmly convinced that they would do no more than restore an old order of things that had been disturbed and violated by the despotism of absolute monarchy or the abuses of colonial government' (ibid., p.34). And her defiant suggestion is that the actual, practical meaning of 'revolution' has largely eluded and remained implicit and vague in the discourse of modern revolutionaries, while political theorists, on their part, have been unable to fully illuminate its 'secret center of gravity' (Wellmer 2000, p. 221). For a commentator on this work like Albrecht Wellmer, this suggestion is only 'radical in a philosophical sense of the word' (Wellmer 2000, p. 222, original emphasis), in the sense that it attempts to introduce new categories into political thought. Yet if one departs from Butler's insight and agrees that the 'grounds' of certain practices of intervention are only graspable on reflection, it becomes harder to underplay the empirical substance of her suggestion.

Any revolutionary experience poses a problem of self-intelligibility, an 'obscurity', as Markell (2010, p. 99) puts it. For it always consists, Arendt reflects, in coming to grips both with 'an entirely new beginning' and with the 'experience of being free' to shape that beginning (Arendt 2006, p. 27, 24). Such an event of political freedom does not lend itself to easy interpretation. It appears as a challenge to those who come to enjoy this freedom, since what they face is the uncertain question of how to deal from that 
moment on with their public affairs, and the future that they share depends on their own decisions, promises and deliberations (ibid., p. 206). If for Arendt 'the shape of revolutionary experience was peculiarly obscure to those who lived it' (Markell 2010, p. 99), it is because making sense of what one is doing and coming to grips with 'the reflection of reflection' or the kind of reflection that is being reflected in practice is the very mark of such experiences.

In spite of that obscurity, Arendt still insists on the notion that 'revolution' can act as a normative criterion of evaluation. There is a kind of absolute measure or 'secret center of gravity' in the revolutionary idea about what it means to successfully realize an intervention. It is in fact a measure that is so absolute that she can confidently sustain, against the grain of much historical common sense, that the American Revolution was much more revolutionary than the French one (see Markell 2010, p. 97). There is a universalism in her account, even if, as Wellmer elucidates, it is only 'the universalism of a human possibility' (Wellmer 2000, p. 229, original emphasis). But such a universal norm would not have been the result of a planned effort or calculated theory. Rather, it would have been the unforeseen outcome of a surprising collective experience unique to modern history, 'unknown prior to the two great revolutions at the end of the eighteenth century' (Arendt 2006, p. 18-19).

Even after having emerged in the perception of Western culture, Arendt's thesis is that the construct of 'revolution' could have only been applied as a criterion of social effectivity retroactively. Against conventional Marxist readings, she finds in revolution the measure of a movement of public action that does more than initiate an unstoppable event, force a violent change, overthrow an old regime, liberate a people or execute a political mission - 'the trouble has always been the same: those who went into the school of revolution learned and knew beforehand the course a revolution must take' (ibid., p. 47). If one wants to speak of something like the core experience of modern revolutions, one must point instead to the opening up of a shared space or 'island' of freedom (ibid., p. 267), one that allows individuals to spontaneously engage in public affairs and express their political passions. In this sense, a successful revolution would be the one that manages to give this space a 'foundation' or institutionalize the experience of political freedom in some way - providing it with a constitutio libertatis (ibid., p. 247). Such a task of foundation would have been from the beginning of the revolutionary tradition difficult to realize and conceptualize, since it is invariably one that must serve to guarantee a phenomenon which in its essence is spontaneous, whose 'preservation in some sense amounts', as Wellmer remarks, to its 'continuous re-invention' (Wellmer 2000, p. 229). This is the eighteenth century 'perplexity' that Arendt believes 'has haunted all revolutionary thinking ever since' (Arendt 2006, p. 224).

Arendt's intention would not have been simply to theorize what revolution should be. The validity of her claims reaches beyond her own philosophy. Her account of revolution is rather a careful exercise in methodology: what method of assessment must one use in order to be consistent with the strategy that a culture has put into motion? After a certain initiative comes into being, which is by nature spontaneous, what effects should one expect and demand from it? What is, in other words, an effective practice of freedom? Constitutio libertatis or 'the foundation of freedom' is not something that can be translated into a stable theoretical presupposition, but it does convey in a way that is 
agreeable and apprehensible enough what we would somehow expect as a culture from a successful revolution.

\subsection{Foundational fractures}

Following Arendt as well as Foucault, Engin Isin has tackled the question of political subjectivity through a rather extreme distinction between 'rupture' and 'convention', suggesting that creative acts can only be investigated through disruptive events and through 'a vocabulary or analytics for understanding acts when subjects fail to follow conventions' (Isin 2012, p. 122, original emphasis). He traces the capacity of freedom to produce an intervention in the field of justice to those 'actions that bring about events as rupture in the order of things' (ibid., p. 126). Conversely, I have read Arendt as a pioneer in the methodological project of grasping the way relationships of freedom with a certain potential for intervention can become institutionalized or at least thematized through the formation of shared conventions. On Revolution can be read as an attempt at articulating a criterion of effectivity that is immanent to action, following the premise that the expression of freedom that revolutionary practice embodies in Western culture already has a discernible principle embedded in it. Arendt elaborates upon this premise at some point:

The absolute from which the beginning is to derive its own validity and which must save it, as it were, from its inherent arbitrariness is the principle which, together with it, makes its appearance in the world ... [Our language] still derives 'principle' from the Latin principium and therefore suggests this solution for the otherwise unsolvable problem of an absolute in the realm of human affairs which is relative by definition. (Arendt 2006, p. 205)

While a relation of freedom signals a kind of 'rupture', 'beginning' or irruptive event, constituting, as it does, a challenge to the expected sequence of social interaction and conduct of the self, the type of irruption that it creates is not always 'arbitrary', as Arendt eloquently puts it. At times, a culture can develop a convention that manages to explain the productivity or 'principle' that comes with it. A 'convention', in this sense, does not entail what a norm normally does. It is not a doctrinal boundary of inclusions and exclusions, a moral condition that is promised to those who adhere to a certain form of behavior. It rather refers to the measure of a difficult accomplishment. As a shared point of reference, it evokes an image of what those relationships look like when they have been successful. But it cannot guarantee that any such relationship, since they are all based on the explosive expressiveness of freedom, will be productive. In brief, instead of providing an ethical 'absolute' - a norm that applies to all cases, even when said norm is recognized to be socially constructed - these conventions offer a strategic 'criterion of effectivity' - a guiding idea or parameter for the kinds of interventions that can be effective in constructing a certain social scenario out of freedom. ${ }^{8}$

To show how conventional a criterion of effectivity for a relationship of freedom can be we can take the example of 'civility', at least in the form Sennett (1992) historically recovers it. Unlike other historical sociologists like Norbert Elias, Sennett finds that the development of codes of courtesy, diplomatic conversation and other self-conscious behaviors in European culture did not necessarily lead to a reduction in social hostility by means of self-restraint and shame-driven self-surveillance. Norms of conduct such as 
being a 'gentleman' were, according to Sennett's research, imagined and devised with the explicit intention of making out of conversation a more pleasurable experience. From its inception in the sixteenth-century literature about the courtier, civility would have thus aimed at more than bodily discipline. It was meant to smoothly facilitate a greater sociability in a hierarchical society, motivating the aristocrat to act politely and modestly in front of others regardless of their rank (Sennett 2012, pp. 116-127).

\subsection{Cultural sedimentation}

In his seminal work, The Fall of Public Man, Sennett relates the modern understanding of civility back to the kind of public game that allowed strangers to interact in the first truly diverse urban centers of the eighteenth century, like London or Paris, at a comfortable distance (Sennett 1992, p. 17). The convention of 'civility' consists for him in the wearing of a mask which incites strangers to fully engage with each other but in a kind of impersonal manner (ibid., p. 264). That mask was for example created at the time by dressing in an overly theatrical form in the street or by adopting a very stylized form of speech in meeting places like the coffeehouse. In both cases, the enactment of a certain public personae allowed strangers to talk to each other openly, expressively, in a kind of fictional mode, unburdened by the frictions, fears and general wariness that come with any difference in occupational rank or social status.

Implicit in Sennett's characterization of civility is an understanding of the individual as a subject capable of relating to others successfully through freedom (see also Haugaard 2016, p. 57-58). 'Convention', he says, referring to the social rituals and verbal cues that signal and drive the embodiment of civility, is itself the single most expressive tool of public life' (ibid., p. 37). It facilitates 'the expression of certain creative powers which all human beings possess potentially - the powers of play' (ibid., p. 264). He uses play and playacting as the explanatory references for this shared capacity for free expression - for the reflection of reflection. Play of the kind children perform among themselves, which as a general rule includes differential levels of skill dependent on age, size and so on, is guided, he suggests, by respect for rules that were found at some point to be satisfying for the enjoyment of all the players involved (ibid., p. 319). Play, in this model presented by Sennett, highlights the crucial role that situational rules can have in social interaction. They make 'risk-taking' possible, while 'mastery over others is put off' (ibid., pp. 319-320). In this sense, the coffeehouse for instance appears as the field for a game that is contained in itself, in which the 'rules' or conventions of sociability have been redefined (ibid., p. 322):

Inside the coffeehouse, if the gentleman had decided to sit down, he was subject to the free, unbidden talk of his social inferior... As men sit at the long table, telling stories of great elaborateness ... they have only to use their eyes and tune their ears to 'place' the stories or descriptions as coming from one with the point of view of a petty-minded petty clerk, an obsequious courtier, or a degenerate younger son of a wealthy merchant. But these acts of placing the character of the speaker must never intrude upon the words these men use to each other ... a frown goes round the table if someone makes an allusion that may be applied to the 'person of any one of his hearers'. (ibid., p. 82)

Sennett's treatment of civility illustrates a number of things. Firstly, it helps to clarify that the challenge of expressing oneself freely is unrelated to the idea that there is an 
authentic self that one can strive to display by avoiding all social formalities and embodying one's genuine motivations. The reflection of one's reflective efforts does not have to allude to a 'quest for personality' (ibid., p. 6) or even, as in the agoras of Ancient Greece and beyond, for 'ethical differentiation' (Foucault 2012, p. 49). It can appear through the ordinary use of a social mask that takes focus away from the self. Secondly, these forms of civility show how quotidian and familiar a scene of freedom can be - how ingrained into a culture a convention of this kind can become, functioning on an everyday basis, casually and indiscriminately between strangers. Finally, and most important, Sennett's study demonstrates how a convention like civility can capture the success of a social scene in which a relationship of freedom has become productive, establishing, for example, an engaging conversation between individuals who, while having a differential of power, agree to let the other one talk unreservedly and leave unmentioned one another's rank and status.

Sennett probably brushed aside the many imaginable occasions in which the powerful would not have actually accepted playing this game once they heard what their subordinates had to say, or it may be that the convention became so agreeable and generalized that the game was for the most part successful. But what is revealing, in any case, is that civility points, as a measure or criterion, to a situational game rather than an absolute norm, to the acceptance of a certain set of mutual rules rather than the tyranny of a fixed standard that separates winners from losers. There is a strange productivity when we observe human relations without the linear lens of power. While we would usually expect from a 'criterion of effectivity' to tell us when someone 'wins' or succeeds in reaching the endpoint in a certain game, 'civility' inside an eighteenth-century coffeehouse tells us that there is a certain effectivity simply when a game of freedom gets to be played.

Once again, it is useful to go back to Foucault and his analysis of parrhesia if we want to elucidate this counterintuitive production of effectivity. The practice of speaking truthfully to someone else, whether that someone was a prince or an ordinary citizen, could not be effective, Foucault emphasizes, unless that other person accepted playing the parrhesiastic game:

The true game of parrhesia will be established on the basis of this kind of pact which means that if the parrhesiast demonstrates his courage by telling the truth despite and regardless of everything, the person to whom this parrhesia is addressed will have to demonstrate his greatness of soul by accepting being told the truth. (Foucault 2012, p. 12)

Parrhesia can be said to be, for this reason, a cultural convention that marks the kind of relationship in which the expression of freedom has not only been manifested, but has also been reciprocated, at the very least with a listening gesture. Parrhesia cannot be a predictive criterion that allows individuals to calculate their actions so as to reach a certain outcome. It can only designate the event by which risky actions acquire an actual effectivity through a certain 'retroaction' (Foucault 2011, p. 68). As a cultural term, it served to make reference to the successful establishment of a pact or game with a powerful subject, but only after a certain courageous player had found himself in a dramatically open situation, faced with binding yet poorly codified risks and effects (ibid., pp. 62-68). 
In the case of relationships of freedom, any criterion of effectivity has to be retroactive. And the reason is not that these relationships are bound to be creative, and the 'truly creative', as White (2008, p. 55) suggests, can only be gathered 'in retrospect'. After all, the calculations that govern relationships of power can also be creative, since they tend to produce - as governmentality scholars have often stressed - applications that differ from the plan, which then feed back into the understanding and refinement of the original model. A relationship of freedom is simply productive in a different way to one of power (in which what matters is just to realize a calculation, for which 'productive' simply means effecting a certain programme). The effectivity of freedom is possible, even in those cases where a more or less vague cultural criterion exists for the situation in question, thanks to the risk involved in advancing that kind of relationship and not in spite of it.

Many individuals who courageously find themselves in dramatic situations never manage to produce a relationship of freedom, even if they follow a procedure similar to those who do succeed. What could be called the parrhesiastic game of listening to the other's truth just does not work out on every occasion, and on the occasions it does work out, it cannot be said to have resulted from a well-executed maneuver. A relationship of freedom always constitutes an event in itself. And, worse, every time a scenario that reflects unique individual reflections reaches the threshold of social productivity to become an event, its existence is threatened by the fact that its achievements are bound to be episodic and transient insofar as they are attributable to courage. Freedom, from this perspective, is to remain a problem.

\section{Conclusion}

One cannot prove that any relationship of freedom has ever actually come into existence. This impossibility of proof has haunted the figure of the truth-teller (Foucault 2011, p. 183) as much as that of the revolutionary (Arendt 2006, p. 86) and of the subject of civil society (Kant 2012, p. 32). In purely empiricist terms, Foucault might have even been right in believing that individuals are always playing the game of 'the conduct of conducts' (Foucault 2000, p. 341). The point, however, is that such a belief cannot be proven either, and that one cannot equate Foucault's sociological purview to a phenomenological dictum of this empiricist sort (see e.g. Dean 2015). He was, rather, interested in tracing the kinds of problems that our culture has put forward for the interpretation of practice (see e.g. Rabinow 2003). To this extent, 'power' would simply have seemed for him to be a pervasive and enduring way of problematizing experience in the Western tradition.

Conceiving the possibility that we, even as 'subjects' or cultural beings subjected to the historicity of norms, are able to relate to each other through a problematic of freedom opens up an opportunity for a 'positive' mode of Foucauldian critique (see Blencowe 2013). The limitation of a strict sociology of power is not that it denies the aspiration to social freedom. In fact, it immediately accepts that 'power is not evil' (Foucault 1997, p. 298) and can facilitate both fair and unfair political conditions. But from a liberal-democratic perspective, it can be frustrating to have to prioritize the importance that such a sociological departure places on suspicious questioning and negative critique, even in those instances where the purpose of power is to enhance our 
socially determined capabilities for freedom (Haugaard 2016). While it may be urgent at all times to disconnect 'the growth of capabilities' from 'the intensification of power relations' (Foucault 2007a, p. 116), one could at the very least - as part of a modern historical conscience interested in improving the terms of human coexistence - prioritize a critical inquiry that asks whether a technology of power encourages the kind of 'reflexive' capabilities that are necessary for self-determination and equal participation in society (e.g. Luxon 2008, Olson 2008).

This paper has not taken that route, however. It instead addresses the liberaldemocratic frustration by amending the original terms of Foucault's sociological proposal. Distinguishing the specificity of a 'relationship of freedom' does not change the order of priorities in the post-structural critique of power. Rather, without appealing to the humanist imperative, this distinction opens up a parallel field of inquiry that is not concerned with 'contestability' (Rose 1999, p. 60; Butler 2015, p. 29) but, rather, with the identification and even stabilization of certain norms, norms that are themselves the product of a cultural critique of power. The 'reflection of reflection' captures a radically different problematic within our culture than that of the 'conduct of conduct', to which a different kind of questioning must be applied. It calls for 'positive' articulation and almost Arendtian optics rather than a 'negative' methodological outlook of defamiliarization and deconstruction.

This positive or constructive focus may still be one that is unwilling to tell us by itself, in any universal manner, whether any such norm is definitely desirable and, most important, whether any given social capability or human embodiment of freedom, such as 'reflexivity', should be systematically targeted and enhanced. 'Civility', for example, can be said to be susceptible to co-optation in the hands of normalizing political programmes and should not be seen as a norm that invariably fosters something like a 'critical capability' (Rose 1999); parrhesia is not exactly a capability for 'resistance' or ethos of civil disobedience but rather a form of exposing oneself and in this sense submitting oneself to the will of the powerful; finally, embracing a cultural narrative of 'revolution' or an 'emancipatory capability' would dismiss the fact that conservative communities have usually been the ones capable of advancing a radical project of social change (Calhoun 2012).

Nevertheless, if among the ways we produce ourselves as subjects, there are some that are orientated away from the problem of power and the concomitant issues of individual objectification that come with the latter, then we should ascribe to them a progressive force or at least potential. Nothing, not even freedom, can be assumed to be impervious to criticism, while complex social organization, at any rate, is bound to require a management of conducts. It may well be that not even those norms that are arrived at through relations of freedom can avoid generating, with the passing of time, a moralizing or exclusionary effect of sorts. But, then again, we cannot expect the project of freedom as a progressive force to be definable in terms of any absolute telos. A civil society built upon relations of freedom should expect, at most, a 'relative' or always revisable telos. ${ }^{9}$ Envisioned as a project or not, freedom is also part of how we act as relational beings, and while hierarchies, calculation, persuasion and power may be logistically unavoidable, freedom can still be considered to be a political compass to continually help us rethink, reshape and restate the open-ended character of our social arrangements. 


\section{Notes}

1. The relative historicist depth of Foucault when compared to Arendt is well addressed and clarified, if somewhat indirectly, by Claire Blencowe (2010).

2. The reference to a skeptical 'capacity' is used here for the sake of clarity, but, as mentioned before, Foucault refers to a much more 'ontological condition' or immanent potential, and, therefore, as I briefly discuss in the conclusion, it could serve as the basis of many different capabilities and ways of giving shape to a subject. Foucault invokes our capacity for skepticism precisely to avoid reifying one or other form of the subject. Skepticism has value for him, but it is not because one can assign to the ones who become skeptical in historically unforeseeable ways a specifiable type of moral worth - such as a Socratic norm of 'respect for open-mindedness and ongoing investigation' (see e.g. Vogt 2012). The skeptical response only offers a 'strategic' value (Foucault 2000, p. 347).

3. Even though I allude to Cynicism as a possible critical inference of Foucault's sociological approach and even though his late studies demonstrate a clear interest in Ancient skepticism (Foucault 2012, p. 190), it must be emphasized that the skeptical capacity he theorizes is in principle disconnected from Skepticism as an epistemological position or doctrine. Such a 'capacity' simply captures the possibility that any individual, regardless of belief or philosophical system, would have of considering alternative options or ways of thinking about a proposition of conduct. This kind of capacity is rather irrelevant from the perspective of ancient skeptics such as Sextus Empiricus (Vogt 2012, p. 150-151). What the Foucauldian and Ancient figures of the skeptic do share, however, is a difficulty in conceptualization since, without adhering to at least certain minimal beliefs (or parameters of conduct mediated by power), a skeptic cannot think (Vogt 2012, ch.6). In the received intepretation of Foucault, power has come to be equated so closely to the normative itself that Butler for example resolves that if all freedom must be performed through inherited normative notions, then the relevant question is how to effect resistance in complicity (Butler 1997b, p. 29-30). The way I can go beyond this residual interpretation of freedom in this paper is by taking seriously the insight recently posed by Paul Kottman (2016), of whether "there really is such a thing as "power" under which all kinds of social and cultural norms can be subsumed and understood' (emphasis added).

4. Only in the rather figurative case of Pericles one sees a governor who governs through parrhesia (Foucault 2011, p. 176-177). But, in general, the practice of parrhesia is simply the agonistic game of discursive confrontation by which the citizens of the polis can achieve the virtuous ascendancy that is required to govern with democratic legitimacy (ibid., pp. 157-158). The right to govern is gained through 'imprecation', by letting the weak confront the powerful (ibid., p. 135).

5. While Foucault uses a variation of the term 'reflection' when he defines ethics as 'the considered [réfléchie] practice of freedom' (Foucault 1997, p. xxv), in his case this terminology has the opposite function to the one I intend to give it here. For Foucault, it serves to qualify - as its tense for example reveals - the practice of freedom as always being an already calculated exercise of conduct.

6. In this sense, my use of 'reflection' is diametrically opposed to that of anthropologist David Graeber, who uses it to differentiate 'the power to act directly on others', or what he calls 'action', from 'the power to define oneself in such a way as to convince others how they should act toward you' (Graeber 2001, p. 104). The way a woman or a king persuades others to treat them in a certain way through a calculated display of the self is for Graeber a form of power that can be defined, rather cross-culturally, as a matter of 'reflection' (ibid., pp. 94-99). In our case, acting upon others through this cross-cultural form of relating to self still belongs to the sphere of the conduct of conduct (see Dean 1995).

7. For Foucault, the 'conduct' of 'conduct' is a suitable definition for power in contemporary academic debates to the extent that it can be derived in a historicist fashion from the thought of Western culture itself as a form of problematization relevant to our modern experience (Foucault 2007b, p. 193). What started as a pastoral concern with the thorough 
management of souls for the sake of salvation eventually translated, after the crisis of the Christian pastorate, into a pervasive secular concern with adequate government in general. The sixteenth century was witness to an explosion of 'needs of conduct' (Foucault 2007b, p. 231) at all societal levels of authority, a problematization that by the eighteenth century had been consolidated into a recognizable political project for rendering entire populations 'governmentable' (Foucault 2008, p.294) or guidable towards a collaborative form of conduct in spite of their own interests and passions.

8. This is a distinction that goes beyond the one Foucault draws between 'morality' and 'subjectivation' (see e.g. Luxon 2008, p. 388-391) and that rather approximates the one I have drawn in another context between 'ethics' and 'strategics' (Palacios 2018).

9. For this conclusion, I am borrowing the distinction between an absolute and relative telos drawn by Dean and Villadsen (2016, p. 142). While they apply it critically to the analysis of Foucault's work on liberal politics and civil society (as a way of ascribing to him a certain teleological remainder), my point is that such a distinction can become important and acquire consistency once the possibility of relationships of freedom has been opened up as a tenable field of concerns within the Foucauldian tradition.

\section{Disclosure statement}

No potential conflict of interest was reported by the author.

\section{Notes on contributor}

Carlos Palacios has just completed his $\mathrm{PhD}$ in sociology, supervised by Mitchell Dean at Macquarie University. His work has most recently appeared in the journal History of the Human Sciences. He is currently working on a monograph titled 'Painfully Humanitarian: Modernity's Intellectual Struggle with its own Radicalism'.

\section{ORCID}

Carlos Palacios (D) http://orcid.org/0000-0003-0464-3479

\section{References}

Arendt, H., 1978. The life of the mind. New York: Harcourt.

Arendt, H., 1998. The human condition. Chicago: University of Chicago Press.

Arendt, H., 2003. Responsibility and judgment. New York: Schocken.

Arendt, H., 2005. The promise of politics. New York: Schocken.

Arendt, H., 2006. On revolution. London: Penguin Classics.

Blencowe, C., 2010. Foucault's and Arendt's 'insider view' of biopolitics: A critique of Agamben. History of the Human Sciences, 23 (5), 113-130. doi:10.1177/0952695110375762

Blencowe, C., 2013. Biopolitical authority, objectivity and the groundwork of modern citizenship. Journal of Political Power, 6 (1), 9-28. doi:10.1080/2158379X.2013.774968

Butler, J., 1995. For a careful reading. In: S. Benhabib, ed. Feminist contentions: A philosophical exchange. London: Routledge, 127-143.

Butler, J., 1997a. Excitable speech: A politics of the performative. London: Routledge.

Butler, J., 1997b. The psychic life of power: theories in subjection. Stanford: Stanford University Press.

Butler, J., 2002. What is critique? An essay on Foucault's virtue. In: D. Ingram, ed. The political. Oxford: Blackwell, 212-226.

Butler, J., 2005. Giving an account of oneself. New York: Fordham University Press. 
Butler, J., 2010. Performative agency. Journal of Cultural Economy, 3 (2), 147-161. doi:10.1080/ 17530350.2010.494117

Butler, J., 2015. Notes toward a performative theory of assembly. Cambridge, MA: Harvard University Press.

Butler, J., 2016. Frames of war: when is life grievable? London: Verso.

Calhoun, C., 2012. The roots of radicalism. Chicago: The University of Chicago Press.

Davidson, A.I., 2011. In praise of counter-conduct. History of the Human Sciences, 24 (4), 25-41. doi:10.1177/0952695111411625

Dean, M., 1995. Governing the unemployed self in an active society. Economy and Society, 24 (4), 559-583. doi:10.1080/03085149500000025

Dean, M., 2013. The signature of power: sovereignty, governmentality and biopolitics. London: Sage.

Dean, M., 2015. Neoliberalism, governmentality, ethnography: A response to Michelle Brady. Foucault Studies, 20, 356-366. doi:10.22439/fs.v0i0.4954

Dean, M. and Villadsen, K., 2016. State phobia and civil society: the political legacy of Michel Foucault. Stanford: Stanford University Press.

Foucault, M., 1988. Politics, philosophy, culture: interviews and other writings, 1977-1984. London: Routledge.

Foucault, M., 1997. Ethics, subjectivity and truth: essential works of Foucault 1954-1984. New York: The New Press.

Foucault, M., 1998. The will to knowledge: volume 1 of the history of sexuality. London: Penguin. Foucault, M., 2000. Power: essential works of Foucault 1954-1984. New York: The New Press.

Foucault, M., 2004. The hermeneutics of the subject: lectures at the College de France, 1981-82. New York: Picador.

Foucault, M., 2007a. The politics of truth. Los Angeles: Semiotext(e).

Foucault, M., 2007b. Security, territory, population: lectures at the Collège de France, 1977-78. New York: Picador.

Foucault, M., 2008. The birth of biopolitics: lectures at the College de France, 1978-1979. New York: Picador.

Foucault, M., 2011. The Government of self and others: lectures at the Collège de France, 1982-1983. New York: Picador.

Foucault, M., 2012. The courage of truth: the Government of self and others II: lectures at the College de France 1983-1984. New York: Picador.

Graeber, D., 2001. Toward an anthropological theory of value: the false coin of our own dreams. New York: Palgrave.

Haugaard, M., 2016. Two types of freedom and four dimensions of power. Revue Internationale De Philosophie, 275 (1), 37-65.

Hirschman, A., 1997. The passions and the interests: political arguments for capitalism before its triumph. Princeton: Princeton University Press.

Hobbes, T., 1998. Leviathan. Oxford: Oxford University Press.

Isin, E.F., 2012. Citizens without frontiers. New York: Bloomsbury.

Kant, I., 2012. Groundwork of the metaphysics of morals. Cambridge: Cambridge University Press.

Kottman, P.A., 2016. What can the human sciences say about freedom today? Politica Comun, 9. doi:10.3998/pc.12322227.0009.009

Luxon, N., 2008. Ethics and subjectivity: practices of self-governance in the late lectures of Michel Foucault. Political Theory, 36 (3), 377-402. doi:10.1177/0090591708315143

Markell, P., 2010. The experience of action. In: R. Berkowitz, J. Katz, and T. Keenan, eds. Thinking in dark times: Hannah Arendt on ethics and politics. New York: Fordham University Press, 95-102.

Olson, K., 2008. Constructing citizens. The Journal of Politics, 17 (1), 40-53. doi:10.1017/ S0022381607080036

Osborne, T., 2003. What is a problem? History of the Human Sciences, 16 (4), 1-17. doi:10.1177/ 0952695103164001 
Palacios, C., 2018. Society, like the market, needs to be constructed: foucault's critical project at the dawn of neoliberalism. History of the Human Sciences, 31 (1), 74-96. doi:10.1177/ 0952695117746045

Rabinow, P., 2003. Anthropos today: reflections on modern equipment. Princeton: Princeton University Press.

Rose, N., 1996. Authority and the genealogy of subjectivity. In: P. Heelas, S. Lash, and P. Morris, eds. Detraditionalization: critical reflections on authority and identity. Oxford: Blackwell, 294-327.

Rose, N., 1999. Powers of freedom: reframing political thought. Cambridge: Cambridge University Press.

Rossi, A., 2017. Foucault, critique, subjectivity. Journal for Cultural Research, 21 (4), 337-350. doi:10.1080/14797585.2017.1370486

Rousseau, J., 1923. The social contract \& discourses. London: Dent.

Sennett, R., 1992. The fall of public man. New York: Norton.

Sennett, R., 2012. Together: the rituals, pleasures and politics of cooperation. New Haven: Yale University Press.

Vogt, K.M., 2012. Belief and truth: A skeptic reading of Plato. Oxford: Oxford University Press.

Wellmer, A., 2000. Arendt on revolution. In: D. Villa, ed. The Cambridge companion to Hannah Arendt. Cambridge: Cambridge University Press, 220-241.

White, M., 2008. Can an act of citizenship be creative? In: E.F. Isin and G.M. Nielsen, eds. Acts of citizenship. London: Zed Books, 44-56. 